\title{
The Problems and Countermeasures of Financial Service System of \\ Domestic small and Medium Enterprises
}

\author{
Zhuo Zhenyun ${ }^{1, a}$ \\ ${ }^{1}$ Jiangxi college of foreign studies,NanChang,330099, China \\ a zuozhenyun@yeah.net
}

\begin{abstract}
Keywords: Small and medium-sized enterprise, financial service system, countermeasure
Abstract. Is the current situation, it seems, whether it is domestic or foreign small and medium enterprises in the country to occupy the position is very important. The reason is that small and medium-sized enterprises in the development process will continue to promote national scientific and technological progress, increasing employment and to expand the country's export, see China's small and medium-sized enterprises in the overall national economic development cannot be copied, is an important pillar of national economic and social development indispensable. Compared to small and medium-sized enterprises to bring enormous contribution, the current national government in the small and medium-sized enterprise development fund table now extremely limited support, coupled with the through external obtained funds difficult, so The financing problems of small enterprises has become enterprise huge obstacles and restricted the healthy development of small and medium-sized enterprises.
\end{abstract}

\section{The different types and function of the financial service system \\ 1.1The types of the financial service system}

Small and medium-sized enterprises are the important impetus of our national economic development. Many domestic science and technology enterprises, small and medium-sized, have gained the recognition of domestic financial services institutions, which we can see that the development potential of small and medium-sized enterprises has been mining day and day. The current domestic big financial institutions start to regard the financial services of small and medium enterprises as the agency of targeted business, and at the same time, many financial institutions focus on the services of all kinds of small and medium-sized enterprises. The majority of the financial institutions regard the technology-based small and medium-sized financial services as the main service object, the agency can form different service scope of major financial institutions according to the scale of the development of small and medium-sized enterprises, the focus of their business and the overall service mode so as to the establish financial service system, the technology-based, for small and medium-sized enterprise, and the system has the characteristics of diversification.

Financial services institutions mainly consist of three parts including banking financial institutions, financial institutions and financial markets. The banking financial institutions providing services for small and medium-sized enterprises mainly include the commercial Banks, non-banking financial institutions, rural financial institutions and policy Banks and 
postal savings bank, among which the non-bank financial sector mainly refers to the trust and financial leasing institutions. Financial institutions mainly include financial leasing institutions, pawn companies, small loan companies, venture investment institutions and credit guarantee institutions, all engaged in the industry with significant financial attributes, but lacking defining the relevant laws and regulations.

\subsection{The functions of the financial service system}

Regarding the resources of the small business, they have abundant labor resources, but they also have very obvious disadvantages. But as a result of unemployment problem for a long period in our country, the problem has become the main obstacles of our country's long-term economic development of the current. The main characteristics of the current domestic small and medium-sized enterprise are wide coverage and fast production, and relatively small investment in the early stages of establishing of small and medium-sized enterprises. The market competition is very fierce, product management is extremely flexible, the requirement for labor resources is very low, thus provides many employment opportunities for many low degree but good ability people in the society in general, which greatly ease the country's employment problems. Many small and medium-sized enterprises offer great many job opportunities in the process of development for the special group in the city, and train the low ability workers before work for the company, and so we can see that the development of small and medium-sized enterprises significantly ease the problems of the state and government in population resettlement.

On the current social development situation, small and medium-sized enterprise present have good developing prospects in the countries all over the world, and kept rising economic status in the developed countries. In the 1990s, many small and medium-sized enterprises had mushroomed version of development in the united states and many high-teched small and medium-sized enterprises are emerging, part of the enterprises successfully share the market. Since then, countries around the world began to put their attention on the development issues of country's small and medium-sized enterprise. Both the developed countries and developing countries, the development of their social economy cannot leave the help of the small and medium-sized enterprises. As the small and medium-sized enterprises has the advantage of their large amount, but its importance of promoting social development not only embodies in the number, mainly embodied in its ability to promote the national economic growth and ease the country's employment problem.

\section{The problems existing in financial service system of the domestic small and medium enterprises}

\subsection{Loan problem}

First of all, the loan problem shows in the performance in the mortgage. Our country's small and medium-sized enterprises have very little mortgage goods and they can only get very few mortgage discount. The current loan mortgage of real estate and land occupies about $70.00 \%$, mechanical facilities account for $50.00 \%$, movable property accounts for $25.00 \%$ to $30.00 \%$, professional facilities account for $10.00 \%$. Assessment level institutions scattered, deal with complex, high cost; capital evaluation agency service does not conform to the rules, or service organization control, and the evaluation of collateral is usually not correct evaluation according to the market rules. 
Secondly, making guarantee is very difficult, which mainly shows in the following: hard to find the right guarantee for small and medium enterprises, and the high efficiency enterprise not only don't want to guarantee for others, also don't want to let others to guarantee for them. Thirdly, the grassroots bank has limited rights, their lending procedures are more multifarious. Small and medium-sized enterprise need to make a serious of procedures when loan amount is bigger which often needs more than a week or even a few months. And even when they get the money, they may have already missed the opportunities.

\subsection{Hard for bank to lend}

Bank lending is the main channel for small and medium-sized enterprise to get financial support. But just a few companies successfully apply for a loan from the bank. According to survey of 345 small businesses in the Guangdong province, when the enterprise have the problem of capital turnover, $70.00 \%$ of the enterprises choose to lend from the commercial Banks and credit agencies to get through the problem. The major means of bank loans is mortgage loan, but loans cycle is short and is hard to success. Among the selecting examination 305 lesson plans, which had applied the bank loans in the past three years but only 135 had the bank loans, and all of them are obtained through mortgages. Credit loans are very rare, only 25 got bank loans, in the absence of mortgage and guarantee conditions, got the help of commercial credit, accounted only $7.00 \%$ of investigated enterprises, which suggests that small and medium enterprises are in very adverse position to get bank loans.

\subsection{The low loan proportion}

The size of the loan services that the state-owned commercial Banks give to small and medium enterprises is gradually improving, but the needs of the loan business of small and medium-sized enterprises keeping prosperity in recent years still have great difference. In the 1990s, our country's small and medium-sized companies got loans from financial institutions accounted around $10.00 \%$, annual average rate increased, but to get loans from a state-owned bank is very low, the proportion is even less than $10.00 \%$. The proportion of lending for small and medium-sized enterprises has been at a lower level. For example, China merchant's bank branch established a small business loan center in Suzhou after passing the examination and approval of Banking Bureau. This is the first financial institutions in our country has the function of a small business loan services specialized in capital. But only a bank China merchants bank can not afford to support financing needs of all the domestic small and medium-sized enterprises, so it requires consistent efforts of all Banks .

\subsection{High debt ratio}

Small and medium-sized enterprise has high debt ratio showing that their capital financing problems or obstacles. From 2000 to 2007, changes of both large enterprises and small and medium-sized enterprises in capital liabilities are not significant, appear slightly lower. But compare the both two kinds of enterprises, capital debt interest rate of small and medium-sized enterprise is nearly $10.00 \%$ higher than large enterprise, which shows that capital model of small and medium-sized enterprise is not high, more dependent on bank financing.

\subsection{Narrow financing channels}

The empirical study of the financing difficulties of small and medium-sized enterprises in our country points out the domestic direct financing channels is narrow, because lending standards high, venture investment system is not perfect, and the approval of the corporate bond issuance. Small and medium enterprises are difficult to raise capital in public through capital market. 
Although Shenzhen's small and medium enterprises template has been established, only a very few companies are suitable to come into the market.

\section{Countermeasures to perfect our financial service system}

Because the small and medium enterprise is the main component of the social economy in micro activities, is the important solution to solve the problem of employment, is also the main part of the economic growth of the country's economic prosperity, to see from the macroscopic angle, the government needs to give legal, financial and policy support to small and medium-sized enterprise to use the power of government to help small and medium-sized enterprise survive and prosperity.

\subsection{First of all, the financial support.}

Small enterprise needs the financial services and policy support from the government. First is to enhance the government's support to help the small and medium-sized enterprise financing, built small and medium-sized loan bank credit specifically for small and medium-sized enterprises to give support to small and medium enterprises on the interest-free and low-interest loans. Second is to release guaranteed financial support policies to fully demonstrate the effectiveness of the government in small and medium-sized enterprises credit guarantee system. Third is to build load financing small and medium-sized enterprise characteristic of the visual system. Part of the manufacturing premises developing second-board market, another part of the initiative to carry out the investment risk.

\subsection{Secondly, the capital support.}

Our country should fully consider the national conditions in China, mainly from the following two phases gradually develop the establishment of the system of government capital suppor with Chinese characteristics of small and medium-sized enterprises. On the one hand, the government should provide the capital support for small and medium-sized enterprise in special things. On the other hand, the government should cancel all the unreasonable charges from the source to prevent chaos to collect fees, reduce tax load of the small and medium enterprises.

\subsection{The last but not the least, the policy support.}

Government's policy support to small and medium enterprises mainly involve the following aspects: borrowing, tax incentives, financial compensation, basic equipment, service, training and information communication mode. Since August in 2008 in our country, a series preferential policy designed to support small and medium enterprises' finance, economy and other aspects have been gradually transformed from strong demand to reality to make prosperity and progress. Different consolidation strength rapidly integrated to solve difficulties and problems for small and medium-sized enterprises in thought and action. Such as the central government supports through the window command, for example, the original loans of the national commercial bank increased by $5.00 \%$; increased local commercial Banks by $10.00 \%$, and points out that these funds must be used in small and medium enterprises or the earthquake disaster areas and agricultural areas, and then releases policy indulgence for the small and medium-sized enterprise loan amount; the highest amount of small guarantee for individuals raised from 20000 Chinese Yuan to 50000 Chinese Yuan; for labor-intensive small businesses small number guarantees the highest amount of borrowing from ten thousand Chinese Yuan to 2 million Chinese Yuan. 


\subsection{Using legal neat credit level of SMES.}

Local governments need as soon as possible to comprehensively promote the Promoting Regulations of Small and Medium-sized Enterprises, continue to abolish the articles of association system which does not conform to the prosperity and progress of SMES, reduce the load of small and medium-sized enterprises in order to make the small and medium-sized enterprise real come into the journey of legalization. Banking Bureau needs to release relevant regulations along with the People's Bank of China jointly, improve the system of private bank entry and exit, make equal competition environment for the market, and provide better loan services for small and medium enterprises as well. In addition, local governments also need to improve mediation system for the small and medium-sized enterprise service.

\section{Summary}

In our country, small and medium-sized enterprise financial development theory as a guide, starting from the successful experience of developed countries and regions in the development of small and medium-sized enterprises, financial service of small and medium-sized enterprises of our country exist problem and reason analysis in a preliminary understanding on the basis of the status quo of China's SME financial service, and put forward feasible countermeasures and suggestions to solve these problems.

\section{References}

[1]Jin Rongxue, Hu Zhiyi, Long Xiaoyan, Innovation of the financial service system of the domestic scientific small and medium enterprises[J],Finance research, 2014,25:23-29.

[2]Wang Muqin, Problems and Countermeasures in the small and medium enterprises during founding[J], The management, 2014,17:169-170.

[3]Dong Biying, Establishment of credit system of our domestic small and medium enterprises[J], Market forum,2015,02:4-6.

[4]Yao Bingqing, Founding situation and countermeasures of our domestic small and medium enterprises[J], Journal of Hubei institute of technology,2015,02:20-22.

[5]Wang Jie, Qiao Xianglan, Founding problems and countermeasures of our domestic s mall and medium enterprises[J],China economy circulation, 2013,10:123-127. 